\title{
Responding To The Concerns Of Student- Athletes Enrolled In A First-Year Experience Course
}

Jeanne L. Higbee, University of Minnesota, Twin Cities, USA Jennifer L. Schultz, Metropolitan State University, USA

\begin{abstract}
This paper summarizes results of a study of 105 student-athletes enrolled in a first-year experience course. Students were asked, "What is the biggest unanswered question you have about college?" Results indicated that students' most burning questions were related to academics; relatively few student responses were directly related to being a student-athlete. Discussion of the findings includes designing first-year experience courses to respond to students' concerns.
\end{abstract}

Keywords: Student-Athletes Concerns; Student First-Year Experience

\section{INTRODUCTION}

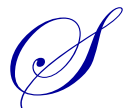

ince fall 2002 the University of Minnesota, Twin Cities has required new student-athletes to participate in a first-year experience course using a standard text (Gardner, Jewler, \& Barefoot, 2008) that addresses a broad range of topics from time management, learning styles, study strategies, career exploration, health and wellness, and stress reduction, to student diversity and intercultural communication. These topics are similar to those covered in first-year experience courses available to students - whether athletes or not - throughout the U.S. and in other parts of the world as well (Executive Summary, 2009; Upcraft, Gardner, \& Barefoot, 2005). In addition, the course addresses issues specific to students participating in National Collegiate Athletic Association (NCAA) Division I athletics programs. The institution decided that any potential negative consequences of segregating students into sections enrolling only student-athletes were offset by the many advantages of being able to respond directly to questions and concerns that arise for this population. The course meets once per week in a large lecture section that often features guest speakers, and then a second time per week in smaller discussion sections that allow for more interaction among students and between students and instructors. The two-credit course has typically been co-taught by a tenured faculty member and athletic department staff. There are regular weekly assignments that are graded by the faculty member and a graduate teaching assistant (GTA). The course is graded A-F, and the course does count in the students' semester and cumulative grade point averages (GPAs).

Attendance in the course is mandatory; more than three unexcused absences (i.e., absences that are not for documented illness or family emergency, participation in athletic competition, or religious observance) results in an F grade in the course. One mechanism that had been used to take class attendance in the large lecture component was weekly question cards. Students picked up a blank card as they entered the lecture hall, where the week's question was projected on a screen. They then turned in the completed card to the faculty member or GTA, who stood at the doors as they left, thus ensuring that no student could submit an extra card for an absent friend. In addition to being credited for attending class, students received 5 points for submitting a card as long as the response reflected serious consideration of the question posed. An inappropriate response typically resulted in the awarding of 1 point; thus, in the grade book it was clear that the student was in attendance, but the student was not rewarded for a flippant answer. Continued loss of points over the semester could result in a slightly lower course grade (e.g., a B rather than a B, which are counted differently in calculating GPAs). The total number of points possible in the course is 1,000 , so the cumulative number of points that could be accrued for submitting question cards did not substantially inflate students' course grades. Examples of weekly questions include the following: 
- What are the top three reasons (in priority order) why you are attending college?

- What are the top three things (in priority order) that distract you from your college academic work?

- What do you think is the most challenging aspect of being a student athlete? Why?

- $\quad$ How do you personally benefit from the diversity of the student body at the University of Minnesota?

- What makes a good faculty member? Do you think that it is OK for a student to question or disagree with faculty? Why or why not?

- What adjective best describes your first semester in college? Why?

This paper summarizes student responses to one of the weekly questions. These responses were then used to provide information to the class as a whole regarding the responses to students' questions, respond individually to students whose questions required a more personalized response, and to guide future course planning.

\section{METHOD}

The question for the third week of class was, "What is the biggest unanswered question you have about college?" This question was intentionally ambiguous; we wanted students to respond spontaneously with whatever first came to mind. By the third week of class students had been on campus long enough to have some awareness of campus resources. As previously noted, students submitted their responses on cards as they left lecture. Of the 122 students enrolled in the course, 109 consented to participate in this research study, and of those 105 were in attendance and responded to this question.

The analysis of responses involved a series of steps. First the faculty member and the GTA separately read each card and developed a list of potential themes. The faculty member then assigned points and recorded grades, while the GTA entered the students' questions in an Excel spreadsheet in no particular order. By the time these tasks had been completed, both the faculty member and the GTA were well acquainted with the ranges of responses and were ready to discuss the possible themes. After the themes were determined, the faculty member and GTA each assigned individual student responses to the following thematic areas:

- $\quad$ Academics: These responses were related to students' academic success. Later in the analysis a subset for items focusing specifically on Examinations was added.

- $\quad$ Athletics: Any item that specifically mentioned being a student-athlete was coded in this category as well as under any other theme reflected in the response.

- $\quad$ Time Management: It was not always clear from the students' responses whether their concerns were related to academics, athletics, or both, as well as other constraints on their time. Later an additional theme, Balance and Stress, was added that overlapped with Time Management, Academics, and Athletics, but did not necessarily involve all three in any given response.

- $\quad$ Future: Concerns for the future might also involve other thematic areas, so many of these items were coded under several themes.

- $\quad$ Faculty: This thematic area was used to code any item in which there was a specific mention of professors, instructors, and so on.

- Major and/or Career: Many items related to career plans also included mention of selecting an appropriate major.

- $\quad$ Navigating the University: These items were related to understanding campus policies and utilizing resources.

- Understanding the University: This theme was created for items questioning how the University of Minnesota functions.

- Health and Wellness: This category included concerns regarding sleep and other factors related to a salubrious lifestyle.

- $\quad$ Finances: This theme was used to code any item specifically mentioning money or financial concerns, including financial aid.

- Social/Interpersonal: This theme was established to include any response related to social life or interpersonal issues. 

responses.

Clearly, these themes were not mutually exclusive, but together they accounted for 104 of the 105

\section{RESULTS}

More than half of the responses (55 of 105) were coded under two or more themes. In discussing the themes, we will include those responses that best fit the particular theme and also discuss some of the areas in which themes seemed to overlap significantly.

\section{Academics, Examinations, and Faculty}

The theme capturing the largest number of responses (55 of 105) was Academics. Some Academics items were related to course requirements, such as, "What classes will I be required to take?" and "Which classes fill requirements?" One student asked, "Why do classes all differ in credit amount?" Another asked, "How am I going to graduate school in 4 years without taking summer school?" And one student asked, "How is it possible to graduate early?" The following student responses reflect other questions related to the Academics theme:

- $\quad$ "Am I studying enough and are my study habits good enough to achieve the grades I want?"

- "Why do we have so much reading to do and not so much worksheet homework?"

- "What order should I study for all of my classes?"

- "Do classes get harder or easier?"

- "What happens to you if you do fail a class?"

- "Am I studying enough to reach my goals of getting all A's?"

- "I wonder if I need a certain GPA to graduate in my major?"

- $\quad$ "How good, or at what level should my writing \& reading skills be at? I feel like I am behind even before I have written any papers."

- "Do I know if how/what I'm studying is right? What I'm studying is completely wrong?"

- " "I'm still not sure about the level of difficulty that I will journey across during my time at college."

- "My biggest question is about college's difficulty. How hard is it going to get? Will it be overwhelming at times?"

- "What is the point of a 20 page paper when you can say the same thing in 3?"

- $\quad$ Although the last of these questions does not specifically mention the instructor, the student appears to be questioning a faculty member's assignment. Six students asked questions in some way related to Faculty:

- "How is it different from high school teachers and college professors?"

- "If I cannot make the office hours for my professor what should I do?"

- $\quad$ "I want to know if the professors think that some excuses are lies to get out of class, like being sick, or something. If they don't believe you could it mean a bad relationship between the student and professor?"

- $\quad$ "I don't know what to do when you can't understand one of your professors.(when your professor speaks another language)."

- "Do instructors really believe that we can read all that they give us to read?"

- "Why do the professors just read off the textbook and not come up with their own examples?"

- Of the 55 items coded under academics, 16 were related to Examinations, including questions like,

- "I haven't had any major exams yet, and I'm still curious about how hard they will actually be."

- "How hard are finals?"

- $\quad$ "How do people study for exams and get good grades? Study tips?"

- "How does the week of finals work?"

- " "I am concerned about finals and how much I have to study."

- "How long should you study for the midterm \& final in each class?"

- $\quad$ "How many hours do people normally study before a major test or exam outside of their normal study hours?"

- $\quad$ "How much more difficult the college exams are compared to the high school styles? Also how much more work you will have to do to prepare for the exams?" 
- "How hard are finals? How long in advance should I begin reviewing?"

- "The biggest unanswered question I have about college is how exams are structured and why they are at night and on the weekends."

- $\quad$ "Am I studying enough now to really help me out during finals week? What is that week going to entail?"

\section{Time Management, Balance and Stress}

There were 12 responses that focused on time management. Typical of these was, "How to study and manage the little time I have, so I can get good grades." Many of the items related to time management focused on finding an appropriate balance between academics, athletics, and other pursuits. One student wrote, "I think that my biggest unanswered question about college is how am I going to be able to manage my entire schedule on a daily basis? It's the third week and already I feel like I am struggling to fit everything in." Thus, stress was an underlying current in some students' questions:

- $\quad$ "Does it ever get easier? Since I have gotten here I feel like there is never enough time in the day. I just keep going with my sport and school. Then in my free time I sleep."

- "Is my life going to be this crazy for 4 years or will it get better? I'm not that overwhelmed, just curious if this is it."

- $\quad$ "Are things going to run more smoothly? Or am I going to feel unorganized all the time?"

\section{Athletics}

Only 19 responses specifically referenced Athletics, such as, "Why are there so many unusual NCAA rules?" Meanwhile, of the 19, 15 were in some way related to Time Management and/or Balance and Stress:

- "What does it mean to be a student athlete? (How do I manage sports and academics?)"

- "Why do athletes have to take a full schedule?"

- "Why do we have to do study hours at Bierman [where the Athletic Department's academic center is housed] even when we don't have any homework left to do and nothing we could get ahead with?"

- " "How do I have more time to hang out between workouts practice and school?"

- "How hard is it to balance homework when in season and traveling?"

- "Does doing homework while playing a sport get easier with time?"

- "To do their best in a sport, do athletes usually do a little less school work to improve in their sport?"

- "How do you get work done when you're out of town with your team?"

- $\quad$ "How will it be each spring semester if I have tennis season? Because at this moment I don't have free time and I'm not playing any tournaments, so I cannot imagine in spring."

- $\quad$ "How to combine the spring season with school, homework, household, practice and all the other things I have to do?"

- $\quad$ "How can we get time to do what we want without thinking about homework, golf (sports) or workouts? When can we have a life? It's like we are so busy and by the time we have time, we are too tired to do anything fun."

- $\quad$ "My biggest question is what happens when I miss class for baseball? What are the steps I have to take to get it okayed and made up?"

- "What is the process is for when I miss class for my sport? How do I make up for those classes?"

- "How do athletes go about getting the information they missed in class while traveling on the road?"

- $\quad$ "How can some athletes load up on like 15 credits, and still find time to get all their work done? I am only taking 13 credits and I have little time to finish all of my work."

\section{Major and/or Career}

Of the 105 responses, 25 were related to the choice of a Major and/or Career, including the following: 
- "How will I choose the right career? What should I look for?"

- "What are some ways to find out what type of career I want?"

- $\quad$ "Are there opportunities or specific programs set up that can help a student-athlete find/get internships at a desired job, regardless of past experience (i.e., no past experience)?"

- "What will my major be? I have narrowed it down to about 4 different things but I really have no idea. So hopefully that question will be answered."

- "What am I going to major in? I have an idea, but I still cannot decide for sure."

- "I am having trouble choosing my major. I know I still have a lot of time. But right now I don't have the slightest clue."

- $\quad$ "Is it important to declare a major early or is it ok to declare towards the end of your second year?"

- $\quad$ "I don't understand what credits \& classes I have to take for CLA [College of Liberal Arts]. Or if I wanna go into something where I don't need a 2nd language. I just wish I knew my major."

Some students had questions related to specific majors:

- "How many people get into the nursing program \& is that the right field for me?"

- "What GPA do I have to maintain to get into my major (kinesiology) and then into grad school for physical therapy?"

- $\quad$ "Will my degree that I eventually earn have a large effect on finding a career? My intended major, broadcast journalism, doesn't seem like it will have a significant appeal to employers in the entertainment industry. A degree in my major doesn't carry nearly as much weight in my professional interests as a $\mathrm{PhD}$ does in medicine. Because my degree might not be specified to my ideal career, will it help me to get a job at all?"

\section{Future Concerns}

As would be expected, there was overlap between questions related to Major and/or Career and those focusing on the Future. Examples include the following items:

- "My biggest question about college is how I am going to narrow down what I want to do with my life."

- "What am I going to do when I'm done with it?"

- $\quad$ "How do you know when and how to decide what you want to do with your education?"

- "How will the university help me once it is time for me to look for a job?"

- "Will college really help me get a good job after I'm done?"

- "How will this college experience affect me? Will it help me get that job that I want to have?"

- "When I have my degree will it set me up with any job I apply for?"

- "How can we be learning skills for our future job if our future job has not been invented yet?"

Other items related to the Future included:

- "What are the keys to a successful college career that lead to a successful life?"

- "How will I be doing after my freshman year?"

- "Will I graduate?"

• "Do you feel like an adult when you're done with college?"

\section{Finances}

There were only three items related to Finances, and one of those also overlapped with Future concerns: "How long, on average, does it take a student to pay off college loans?" The two other Finance questions were specific to the students who asked them: 
- $\quad$ "I want to know why financial aid is so difficult to attain. It was presented as an easy process but it is taking a long time for myself to be done with it."

- $\quad$ "If on my student account bill it says I owe $\$ 720$, but when I click pay online it says I owe $\$ 4000$. Do I have to pay the $\$ 4000$ and get money back or do I just have to pay the $\$ 720$ ?"

\section{Themes With Few Responses}

For several of the themes there were only a few coded responses. Perhaps most notable was the Social/Interpersonal theme, with only two responses beyond those regarding time management that might be construed as including little time for social life. One student asked, "How do you deal with a roommate that you are having difficulties with?" Another student wanted to know, "Is it normal to feel kind of depressed because you miss people back home?" Both of these questions prompted individual meetings with the students who asked them.

There were also only two responses focusing on Health and Wellness: "How do I get enough sleep?" and "Why do students throw away their college careers, athletics, and/or any opportunities by drinking?"

Several students asked questions about navigating the University beyond those related to required courses, choosing a major, and other responses that were coded in more than one theme. Examples included:

- "Where are all of the dining halls? Where and how can I print off papers and assignments and does it cost money? How do I pay?"

- "Where do the 'limited stop' campus connectors stop?"

- "How will I get around when it starts to snow?"

Finally, two students asked questions about the University. The first wanted to know, "How does this huge University work? I mean how complex is the organization of this school? How many people work for that? Which kind of problems are there?" The other student asked, "What is the most chosen degree for students at the U of M?"

Of the 105 responses, only one was flippant: "Why is [name of individual student enrolled in course] the fastest, most cool person on the [sport] team, as well as the entire campus?" This question was submitted by a teammate of the student named.

\section{DISCUSSION}

Perhaps the most notable result of this research was the students' focus on academic- and career-related issues rather than on athletics. Some educators stereotype student-athletes as prioritizing participation in their sport over their scholarly pursuits. The results of this study indicate that the student-athletes enrolled in this first-year experience course were concerned about performing well academically. They were also concerned about their futures, and specifically about choosing a major and career and finding a job. Clearly many were not assuming that their future career would be in their sport.

The number of responses related to time management and to finding a balance between academics and athletics was not surprising. We hypothesize that if this study is replicated with students who are not studentathletes the results will be similar, although the students would be discussing balancing academics with employment, family responsibilities, and other priorities for their time.

It was surprising that so few of the students' questions pertained to finances. Not all student-athletes receive full scholarships, and even those who do often feel financial constraints because they cannot take on parttime employment and do have expenses that are not covered by their scholarships (e.g., car payments, winter clothing for those who come from warmer climates). It is likely that if this research is replicated with students who are not student-athletes, there would be a greater emphasis on questions related to financial aid and other matters related to the costs of a college education.

We also expected more questions related to social life. Based on these results, it might be assumed that social life takes a back seat to academics and athletics for this group of student-athletes. 


\section{IMPLICATIONS}

This research affirmed that for the most part the course already addressed topics of concern to students, including differences between high school and college, time management, choosing a major and career, and stress management. Based on these results, a discussion section meeting was devoted to detailed coverage of how to study for and take examinations. In addition to general coverage of career exploration, students were introduced to the University's decentralized career services offices, which are housed in the separate colleges of the University.

This course was identified as a pilot for the University's new online graduation planning tool. The University's registrar and members of her staff introduced the tool in lecture, and then worked with students in a computer lab during discussion to complete a 4-year plan within the student's major. Undecided students could develop a plan that would be workable for most majors within the University's largest college, the College of Liberal Arts. The Registrar's Office and the College of Education and Human Development (the faculty member of record's tenure home) collaborated on a new video featuring successful student-athletes discussing their academic challenges and achievements.

Finally, within 1 week of collecting these question cards, students received a handout with responses to many of the questions posed. For example, although only one student had discussed feelings of loneliness, this topic was addressed at length because it was assumed that other students were likely to be feeling lonely and homesick as well. On a less serious note, providing information about bus lines and dining halls was easy to do, and the handout also included information about where to get the answers to other questions of a similar nature. The University of Minnesota, Twin Cities is proud of its OneStop service, through which students can get quick answers to a wide range of queries either online or face-to-face.

\section{CONCLUSION}

This research study was simple to conduct and yielded information we considered valuable in future development of this first-year experience course. It also enabled us to answer questions regarding student concerns. It would be interesting to replicate this research with students who do not participate in Division I athletics. We hypothesize that there would not be significant differences in the responses, although we would anticipate more student questions about financial issues. In general, we believe that this study supports the genuine interest of student-athletes in being good students and in preparing for a career beyond athletics.

\section{AUTHOR INFORMATION}

Jeanne L. Higbee has worked in higher education since 1974, first in student affairs, and since 1985 in faculty positions. She currently serves as Professor and Director of Graduate Studies for the Department of Postsecondary Teaching and Learning in the College of Education and Human Development at the University of Minnesota, Twin Cities. She is a 2011 recipient of the Horace T. Morse-University of Minnesota Alumni Association Award for Outstanding Contributions to Undergraduate Education as well as the University of Minnesota Intercollegiate Athletics Department's Tom H. Swain Campus Recognition Award honoring her commitment to the academic success of studentathletes. E-mail: higbe002@umn.edu (Corresponding author)

Jennifer L. Schultz earned tenure in 2012 and is an Associate Professor in Human Resource Management (HRM) for The College of Management at Metropolitan State University in Minneapolis, Minnesota. She serves as the Curriculum Coordinator for the undergraduate HRM program and teaches graduate and undergraduate courses in management and HRM. She earned her Ph.D. from the University of Minnesota, Twin Cities, where she served as the graduate teaching assistant for the course described in this paper. E-mail: Jennifer.Schultz@ metrostate.edu 


\section{REFERENCES}

1. Executive Summary. (2009). National survey of first-year seminars. Columbia, SC: University of South Carolina, National Resource Center for the First-Year Experience and Students in Transition. Retrieved from http://www.sc.edu/fye/research/survey_instruments/pdf/updates/Executive_Summaries_2009_National_Survey _First-Year\%20Seminar.pdf

2. Gardner, J. N., Jewler, A. J., \& Barefoot, B. O. Your college experience: Strategies for success ( $8^{\text {th }}$ ed.). Belmont, CA: Wadsworth/Cengage Learning.

3. Upcraft, M. L., Gardner, J. N., \& Barefoot, B. O., \& Associates. (2005). Challenging and supporting the first year student: A handbook for improving the first year of college. (2005). San Francisco, CA: Jossey-Bass. 